\title{
An Analysis of the Bank Credit Marketization's Effects on the Economic Fluctuation in China
}

\author{
Zhang Jing $^{1}$, Hu Xiangshun ${ }^{2} \&$ Yin Qiuyan ${ }^{1}$ \\ ${ }^{1}$ School of Finance, Shandong University of Finance and Economics, Shandong, China \\ ${ }^{2}$ University of Bradford, England \\ Correspondence: Zhang Jing, School of Finance, Shandong University of Finance and Economics, No. 40 \\ Shungeng Road, Jinan City, Shandong Province, 250014, China. Tel: 86-138-6911-2681. E-mail: \\ zhjyzhr@163.com
}

Received: August 5, 2015

Accepted: September 6, 2015

Online Published: October 25, 2015

doi:10.5539/ijef.v7n11p140

URL: http://dx.doi.org/10.5539/ijef.v7n11p140

\begin{abstract}
In recent years, more and more scholars began to emphasize the study of factors affecting macroeconomic fluctuations. As the bank credit market is a major part of the financial market in China, how bank credit marketization influences economic fluctuation has undoubtedly caused much attention. This paper mainly studies the role of bank credit marketization in the conductive process of macroeconomic fluctuations caused by real shocks and monetary shocks. According to the theoretical model created by Bacchetta (2000) and Beck (2006), this paper theoretically analyses the mechanism of bank credit marketization's effects. The results show that bank credit marketization amplifies real shocks but offsets monetary shocks in the conductive process of macroeconomic fluctuations. The government scale and the development of the stock market also have a significant influence on economic fluctuations. Based on the theoretical and empirical analysis, some policy recommendations are proposed.
\end{abstract}

Keywords: bank credit marketization, economic fluctuation, real shocks, monetary shocks

\section{Introduction}

Business cyclical fluctuation which plays an important role in macro-economy operation has been a hot topic for many years. With the arrival of the economic crisis in recent years, more and more scholars began to emphasize the study of factors which affect macro-economy fluctuation. Among these studies, the relation between financial marketization and economic fluctuation is a leading research field. Because bank credit is one main component of the financial market in China, the influence of the extent of bank credit marketization on economic fluctuation becomes a hot topic of discussion.

Related literature showed that the developed countries experienced a process that macro-economy volatility decreased continuously in the 20th century, especially after World War II. Some economists called the process that U.S has reduced economic volatility since the mid of 1980s as the "Great Moderation". Most European and American economists attributed this economic phenomenon to the economic system, especially to the continuous development and perfect of financial market system. Similar to the developed countries, Chinese economy has kept developing in the volatile conditions. Since 1949, the country has experienced 10 business cycles, among which, from the first five-year plan (1953) to start large-scale industrialized construction to the end of the cultural revolution (1976), China experienced five economic cycles. However, since 1978, especially since the mid 1990s, the characters of Chinese economic cycles have changed significantly, and the extent of economic fluctuations has been falling and economic stability has been increasingly strengthened, so the mode of economic cycle fluctuation in China is transforming "big rise and fall" to "small rise and fall" gradually.

Then, since the middle of 1990s, what has made the extent of macroeconomic fluctuation decline gradually?

According to China's bank-oriented financial system, after implementing the commercialization reform in 1990s, China's financial system has been developed rapidly and comprehensively, and the scale of the financial system has been expanded quickly and the efficiency of financial system has been improved a lot; the extent of bank credit marketization has been significantly higher than before. This happens to coincide with the steady economic operation period. It seems that the bank credit marketization of China is related to macroeconomic 
fluctuation, so this study attempts to examine the relationship between the two theoretically and empirically.

Considering that studies on the reason of Chinese macro-economic fluctuation reduction and the relationship between financial marketization, especially bank credit marketization and economic fluctuation have still remained in a primary step, and deep systematical analysis of internal mechanism and level of influence of the above mentioned problems is inadequate, an analysis of those problems will not only make up for Chinese deficiency of studies on the relationship between the development of bank credit marketization and economic fluctuation in the economy theory field, but also provide a theoretical basis for the government so that it can make further effective financial reform policies to promote the development of Chinese financial system and the maintaining of the steady growth of Chinese economy.

\section{Literature Review}

Researches about the relationship between the economic development and the macroeconomic fluctuation has been on the rise only for the recent decade worldwide, and there are not many researches specially aiming at analyzing the influence of the bank credit marketization on macro-economic fluctuation. So, we synthesize the relative literature about economic development, financial marketization, financial intermediaries and bank credit. Considering the huge difference of the existing conclusions, we arrange them into the following three categories.

\subsection{The Bank Credit Marketization Reduces Macro-Economic Fluctuation to Some Extent}

\subsubsection{International Literature}

Bernanke and Gertler (1989), Bernanke, Gertler, and Gilchrist (1996), Kiyotaki and Moore (1997) concluded that the incomplete bank credit market should have a significant influence on the external economy and could amplify the economic fluctuation by the Financial Accelerator Effect while the completing of bank credit market could slow economic fluctuation by weakening the Financial Accelerator Effect.

Hausmann and Gavin (1996) found that the cause of the comparatively dramatic economic fluctuation in Latin American countries was the economic structures and economic policies in the research of the developing countries in this area. And the bank credit marketization was in favor of absorbing and digesting economic shocks so that the macroeconomic fluctuation could have been slowed while insisting on pegged exchange rates system might lead to a more dramatic economic fluctuation.

Easterly and Stiglitz (2000) tried to reveal the cause of the output fluctuation in OECD countries, and they found that wage rigidity theory which was in the core position of traditional Keynesianism had nothing to do with it. On the contrary, some financial ingredients ignored by traditional theory played an important role in explaining the macro-economic fluctuation and economic transformation.

Denizer, Iyigun, and Owen (2002) made an empirical study on panel data of seventy countries from 1956 to 1998 and the result suggested that financial system and the development of bank credit market was essential in slowing economic fluctuation: the more developed financial system and bank credit market a country had, the comparatively less obvious fluctuation of output, consumption and investment per capita a country was with. In addition, they found that the relative importance of banking industry in financial structure effectively explained the fluctuation of GDP, consumption and investment.

Raddatz (2006) studied countries with less developed financial system and he found that finance with different levels of development had obviously different influences on macroeconomic fluctuation. Financial development leaded to economic fluctuation mainly by increasing manufacturers' marginal output and the development of financial intermediaries was more effective in slowing the fluctuation than stock markets.

Wang and Wen (2009) believed that the development of financial intermediaries gave rise to the increase of risk administration, making enterprises' irreversible fixed investment more sensitive to economic shocks so that when different enterprises encountered heterogeneous shocks, albeit there was large volatility in enterprises' investment, there was small fluctuation in general investment in the financial system.

Aghion et al. (2010) and Cacciatore et al. (2015) argued that the development of financial intermediaries enhanced the countercyclicality in long-term investment by smoothing credit market information circulation, which was in favor of preventing dramatic economic fluctuation.

\subsubsection{Chinese Literature}

Guoyu Sui, Yi Lan (2005) pointed out that the development of financial system, the rigidity of state-owned enterprises' budgets and the gradually optimal distribution of scarce resources such as financial resources between state-sectors and non state-sectors were the main causes of the reducing economic fluctuation and growing economic stability in China. 
Li Dong's (2006) and Bing Zeng's (2015) research showed that the rapid development of Chinese financial market had an important influence on slowing growth fluctuation and bank credit was more effective in slowing output fluctuation than stocks market.

Zhen Xinluo et al. (2009) found that the development of bank intermediary had an inhibitory effect on monetary shock, while it did not perform an obvious amplification of entity economy shock.

Zhu Tong et al. (2011) research also showed that the marketization of bank credit and the completing of financial system itself counteracted the influence of external shocks on the fluctuation of real GDP per capita and real fixed investment per capita to a large extent, which effectively reduces the economic sensitivity to external shocks in China.

\subsection{The Bank Credit Marketization Aggravated Macroeconomic Fluctuation}

\subsubsection{International Literature}

Stigilitz $(1981,1996)$ proposed financial restriction theory. As far as he was concerned, for the developing countries, finance marketization leading to a rapidly rising interest rate would not only deteriorate the bank credit investment but also be destructive to financial system stability. According to this, a rising interest rate caused by bank credit marketization was the key factor leading to financial instability.

Kaminsky and Reinhart (1996) and Pitterle, Haufler and Hong (2015) found that in most cases, bank credit marketization came along with termination of capital controls: Domestic banks undertook the foreign exchange risk because they borrowed foreign currency funds and lent them to domestic borrowers.

Demirg-Kunt and Detragiache's (1998) research showed that bank credit marketization diminished the value of banks' franchise and then it aggravated financial fragility.

Dellas and Hess (2002) and Bartram and Wang (2015) focused on financial development's influence on price in stock market. They took many, both domestic and foreign, factors into consideration to test whether the sensitivity of domestic stock returns will change systematically along with the changing level of local financial development. They studied data from forty-two countries, from 1980's to the middle and later of 1990's and they found that financial development made one nation's financial or stock market more sensitive to foreign economic shocks and the change of stock returns would influence economic growth and fluctuation.

\subsubsection{Chinese Literature}

Bai Dangwei (2004) found that financial deepening could promote the development of financial market and financial intermediaries: Foreign effect influencing economic fluctuation could be transmitted to domestic financial environment by assets combination, wealth effect and international capital loan.

Du Ting and Pang Dong (2006) tested the correlation between financial development and economy circle from the perspective of the development of bank credit marketization, interest rate trend and stock market in China, and the result showed that the development of Chinese financial intermediaries and bank credit marketization aggravated the fluctuation of economic growth.

\subsection{There Existed Multiple Effects in Financial Development's Influence on Macroeconomic Fluctuation}

Bacchetta and Camina (2000) built a general dynamic equilibrium model to analyze the relationship between bank credit marketization and macroeconomic fluctuation. The conclusion was that economic shocks should influence macroeconomic fluctuation for relocation funds between manufacturers because of different marginal product of capital from different manufacturers, and bank credit marketization would counteract economic shocks' influence on macroeconomic fluctuation because of information asymmetry.

Aghion et al. (2004) built a model where only after the development of financial intermediaries was beyond a certain threshold level would it have inhibitory effect in economic fluctuation.

Thorsten et al. (2006) and Ogawa (2015) based on the assumption that financial intermediaries were created to reduce agency cost and restrict entrepreneur' cash flow, used panel data for empirical analysis. They found that it was not necessary that economic shocks would aggravate fluctuation in economic growth, and the development of financial intermediaries counteracted the shock of multi-sector economy and amplified monetary shock.

\subsection{Summary}

From the literature above, it can be found that as situations vary from country to country, no single conclusion has been reached on the influence of bank credit marketization on economic fluctuation and special researches are short, both in China and abroad. Especially in China, before the reform and opening-up policy, research on fluctuation in economy circle had been scarce for a long time and the limited research was illustrative, focusing 
on describing Chinese fluctuation path in economy circle, because fluctuation in economy circle had been regarded as the specific product of capitalistic economy by economy theory field. Only in recent years there are some scholars who have noticed the fact that Chinese macroeconomic fluctuation leveling out and attempting to analyze this matter from the perspective of financial development. In the existing literature, most Chinese scholars used foreign theoretical models for reference. However, the empirical results are unsatisfactory, suggesting that complete applying foreign models without combing specific national conditions cannot explain Chinese situation. Besides, because the research method and data are dated as referable literature is dated, theoretical analysis does not agree with empirical results, which makes it not ideal to test the results of theoretical results. This article attempts to combine relative models with Chinese conditions and to make an empirical test based on data closely related to Chinese conditions so that it can make up for the Chinese deficiency in the yield of studying the influence of bank credit marketization on economic fluctuation.

\section{Theoretical Analysis}

This study analyzes the role that the development of bank credit marketization plays in the conductive process of economic fluctuation leading to output fluctuation by referring to Bacchetta (2000) and Beck (2006)'s model and combining with the actual situation of China. The main analysis framework of this article is: because of the information asymmetry, borrowers are subject to credit constraints, and because borrowers have different marginal productivity from depositors, when economic shocks occur, the money is redeployed between borrowers with credit constraints and depositors without credit constraints, which will have further amplification effect or offsetting effect on macro-economy.

\subsection{Equilibrium Analysis on Credit Market}

The model of this study includes two kinds of participants: producers (manufacturers) and consumers, and this study assumes that all producers have the same production function, of which the capital input $k$ is the only production factor, and producers have different endowments, the original wealth $w$. According to the difference of original wealth $w$, producers can be divided into two types: one type of producers occupies more endowments denoted by $H$, while the other type of producers has fewer endowments denoted by $L$. Because the former type of producers occupy more original wealth, which can not only meet the demand of their own investment and can be left. The left funds are deposited into commercial banks and the interest rate on deposits is assumed as $R^{d}$. However, because the original wealth of the other type of manufacturers cannot meet their demand of their own investment, they have to borrow money from banks, and the interest rate on borrowings is assumed as $R^{l}$.

The production function is:

$$
y=f(k)
$$

And it can meet the demand that $f^{\prime}(k)>0, f^{\prime \prime}(k)<0$, which means the production function is concave. If we take the derivative of these two different types of producers, we can get the following conclusion.

$$
\begin{gathered}
f^{\prime}\left(k^{H}\right)=R^{d} \\
f^{\prime}\left(k^{L}\right)=\alpha \cdot R^{l}(\alpha \geq 1)
\end{gathered}
$$

Formula (2) reflects this economic meaning: the producers with deposits in bank meet the optimal configuration: The marginal output of capital elements should be equal to the deposit interest income which is from the money deposited in banks. In the formula (3), $\alpha$ is the agency cost, due to the information asymmetry of investment project, the producers with borrowed funds have "shirking" motivation and other moral hazard problems, as a result, firms borrowing from banks will also face the problem of agent cost, and their optimal capital input $k^{L}$ is: the marginal output of capital element is equal to the cost of capital using in consideration of agent cost adjustment. We can find that because $f^{\prime \prime}(k)<0, f^{\prime}(k)$ is a decreasing function, then the higher $\alpha$ is, the lower the capital input of firms borrowing from banks. At the same time, for the capital input is the only factor in economy, in the case of given production function, the change of the capital input is the only determinant of the macro-economy volatility. Because borrowers have larger marginal output of capital, the capital input of borrowers is the leading cause of output fluctuations.

If we make two sides of formula (2) divided by two sides of formula (3), we can get the following equation.

$$
\frac{f^{\prime}\left(k^{L}\right)}{f^{\prime}\left(k^{H}\right)}=\alpha \frac{R^{l}}{R^{d}}
$$


As you can see from the formula (4), the higher the agent cost $\alpha$ or the larger the interest spreads between deposits and loans $\frac{R^{l}}{R^{d}}$, the larger the value of the left side, too. Because of the nature of function $f(k)$, it also means that $\frac{k^{H}}{k^{L}}$ is bigger. In the case of given production function, the reconfiguration of money between the two types of producers will affect the gross output of the economic system.

It is because of the information asymmetry in the economy, financial institutions came into being, and well-funded producers would deposit idle funds to commercial banks, while cash-strapped producers would get a loan from banks. In order to facilitate analysis, this study also assumes that deposited financial institution is a completely competitive market without operating costs. According to monetary authorities' requirements of deposit reserves, banks can offer loans only after withdrawing enough deposit reserves. We assume that the deposit- reserve ratio is $\tau$, and commercial banks can provide loans which are only $(1-\tau)$ of all deposits. To make the credit market balanced, the aggregate supply of deposits must be equal to the total demand of loans:

$$
\begin{gathered}
(1-\tau)\left(w^{H}-k^{H}\right) \beta^{H}=\left(k^{L}-w^{L}\right) \beta^{L}(1-\tau) \\
\beta^{H}+\beta^{L}=1
\end{gathered}
$$

The left side of formula (5) is loan supply of commercial banks, while the right side is producers' demand for loans. $\beta^{H}$ is the proportion of well-funded producers (entrepreneurs); correspondingly, $\beta^{L}$ is the proportion of cash-strapped producers. It is easy to find that in the model we built, commercial banks have two functions: capital surplus adjustment and monetary policy transmission.

In the above formula (5), under the condition of market equilibrium, the amount of deposits and loans is certain, the interest rates of depository and loan are only related to the deposit-reserve ratio. In China, because the interest rates of depository and loan are controlled by the central bank strictly, the interest rates of depository and loan can be seen as another kind of means of control.

Therefore, we change the original model properly to get the following formula:

$$
\frac{R^{d}}{R^{l}}=\theta+\rho(1-\tau)
$$

This study considers related factors of agent cost of producers with credit constraints and base on the research findings of Bacchetta (2000) to build the following equation:

$$
\alpha=\omega \frac{k^{L}-w^{L}}{k^{L}}=\omega \cdot\left(1-\frac{w^{L}}{k^{L}}\right)
$$

In formula (8), $\omega$ is a technical indicator. It can be seen that the stronger the technicality of investment projects or more intense the investment demand of borrowers, namely, the greater $\frac{k^{L}-w^{L}}{k^{L}}$, the higher the agent cost. It is important to note that agent cost $\alpha$ is mainly determined by manufacturers' proportion of free capital and invested capital $\frac{w^{L}}{k^{L}}$, rather than absolute level of free capital $k^{L}$. If we substitute formula (8) into formula (4), we can obtain:

$$
\frac{f^{\prime}\left(k^{L}\right)}{f^{\prime}\left(k^{H}\right)}=\omega\left(1-\frac{w^{L}}{k^{L}}\right)[\theta+\rho(1-\tau)]^{-1}
$$

From the above formula, we can conclude that the investment proportion of the two types of producers $\frac{k^{L}}{k^{H}}$ is related with the proportion of internal financing for borrowers $\frac{w^{L}}{k^{L}}$, agent rate $\omega$, interest spreads between deposits and loans $\theta$ and deposit-reserve ratio $\tau$. 
At the same time, we retested the condition of general equilibrium to get the following formula:

$$
\beta^{H} w_{t}^{H}+\beta^{L} w_{t}^{L}=\beta^{H} k_{t}^{H}+\beta^{L} k_{t}^{L}+\tau \beta^{H}\left(w_{t}^{H}-k_{t}^{H}\right)
$$

The left side of the above formula means initial wealth of all producers, and the right side is divided into three parts: Two types of producers' investment in $t$ period and deposit-reserve ratio withdrew by commercial banks.

\subsection{Multiple Effects Analysis of Commercial Banks}

First we consider the real shocks, that is, we exam the effect of macro-economy fluctuations. In the case of discrete time, we assume that economy has an unexpected positive shock in $t$ period: $y_{t}=\varphi \cdot f\left(k_{t}\right), \varphi>1$. Then, this study examines the shock's influence on economy in $t+1$ period and gets the following formula:

$$
\begin{aligned}
& w_{t+1}^{L}=\eta^{L}\left[\varphi \cdot f\left(k_{t}^{L}\right)-\left(k_{t}^{L}-w_{t}^{L}\right) R^{l}\right] \\
& w_{t+1}^{H}=\eta^{H}\left[\varphi \cdot f\left(k_{t}^{H}\right)+\left(w_{t}^{H}-k_{t}^{H}\right) R^{d}\right]
\end{aligned}
$$

By comparing $\frac{w_{t+1}^{L}}{w_{t+1}^{H}}$ with $\frac{w_{t}^{L}}{w_{t}^{H}}$, because of their leverage corporation $\left(\frac{k^{L}}{w^{L}}>1\right)$, borrowers can derive more advantages from growth of the positive economic shock, therefore, the wealth of borrowers (producers with lower endowments) increases relatively faster than that of depositors (producers with higher endowments). We can get that $\frac{w_{t+1}^{L}}{w_{t+1}^{H}}>\frac{w_{t}^{L}}{w_{t}^{H}}$. Because of the increase of initial capital, in the investment of $t+1$ period, borrowers will input more owned capital $w_{t+1}$, which leads $\frac{w_{t+1}^{L}}{k_{t+1}^{L}}$ to increase. At the same time, from formula (8), we can further find that with the increase of $\frac{w_{t+1}^{L}}{k_{t+1}^{L}}$, the agent cost of borrowers is declining because the agent cost change against the economic fluctuation. So the agent cost has a magnified effect in the economic cycle. According to "financial accelerator" theory, this study deduces that:

\section{Corollary 1: The bank credit marketization has an amplification effect in the process of real shocks which give rise to macroeconomic fluctuations.}

Second monetary shocks are analyzed, which is relatively complicated, because in the process that monetary impact giving rise to the output fluctuations, monetary shocks on economic fluctuation are mainly indirect. We assume that there is time lag of monetary shocks on the economy, the monetary shocks in $t$ will reflect to macro-economy in $t+1$.

On the one hand, in the hypothesis of a perfect financial market, as there is no transaction costs, financial institutions don't exist, either, so that we needn't consider agent costs. According to formula (9), we just need to consider the second part of the right formula. If there are positive monetary shocks, such as interest rate adjustment ( $\theta_{t}$ increase) or the deposit-reserve ratio adjustment $\left(\tau_{t}\right.$ reduce), according to formula (7), it will cause output to increase significantly, which will lead to the larger extent of macroeconomic fluctuation necessarily.

On the other hand, in the actual economic environment with transaction costs, the positive monetary shocks (such as $\theta_{t}$ rise or $\tau_{t}$ fall) will increase the supply of loanable funds, so borrowers will receive money more easily. From formula (5) and (10), the monetary shocks are bound to improve the leverage of borrowers, which 
means that $\frac{k_{t+1}^{L}}{w_{t+1}^{L}}$ is about to be bigger. From formula (8), the increase of $\frac{k_{t+1}^{L}}{w_{t+1}^{L}}$ will inevitably lead to the increase of borrowers' agent costs, which is equal to the increase of $\omega \cdot\left(1-\frac{k_{t+1}^{L}}{w_{t+1}^{L}}\right)$. Then according to formula (9), in the case of other conditions unchanged, the capital inputs of borrowers $k_{t+1}^{L}$ will be reduced. The reduce of inputs of borrowers will inevitably lead to lower output, which will counteract the positive effect in the process that monetary shocks give rise to output fluctuations. On the basis of the above analysis, this study deduces that:

Corollary 2: The development of bank credit marketization has an offset effect in the conductive process of monetary shocks which give rise to macroeconomic fluctuations.

\section{Empirical Analysis}

\subsection{Index Construction and Variables Description}

\subsubsection{Economic Fluctuation Measures}

The output in modern economy is usually increasing, and economic fluctuation shows mainly economic growth rate fluctuation. Given this, this study measures the extent of macro-economic fluctuations on the basis of per-capita real GDP growth rates. In order to identify the periodic components in economic growth, we adopted band-pass filtration method. Band-pass filtration method can make some periodic components at a certain frequency range get through the filter and intercept the trend components with the lower frequency and random components with the higher frequency. Common band-pass filtration method includes BK band-pass filtering and CF filtering. Relatively, because the demand of BK filtration method is fluctuation symmetry and CF filtration method needs anti-symmetric filter, which makes BK filtration method limited. Because Liu Shucheng et al. (2005) found that economic fluctuation of China has been obviously asymmetric since the reform and opening up, this study uses CF filtration method based on eviews6.0 to identify the fluctuation components of economic growth. The result is shown in Figure 1 ( $E F$ is annual date of per-capita real GDP growth rates. The non-cycle is the trend component, and the cycle is the fluctuation component).

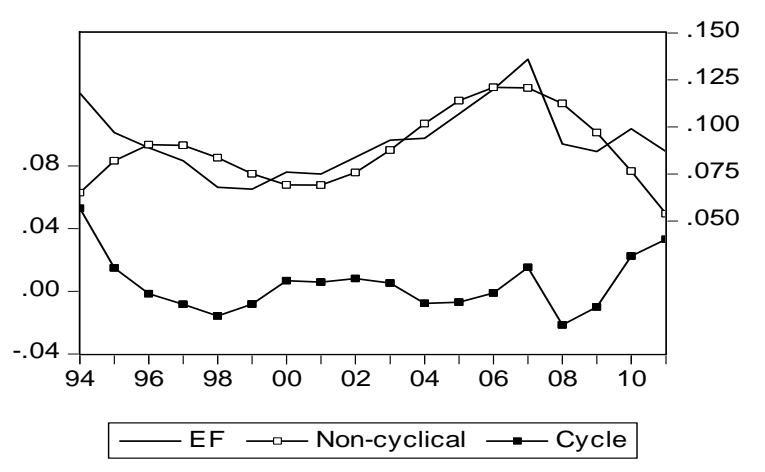

Figure 1. Per-capita GDP growth

\subsubsection{Bank Credit Marketization Measures}

Based on Chen Bangjiang (2008), this study uses the non-state-owned enterprise loan (i.e. the township enterprise loan + individual private enterprise loan + three-funded enterprise loan) to measure the level of bank credit marketization. Because credit expansion is often a government behavior in China, state-owned enterprises have strong impulses to invest, while there is "soft constraints" problem in state-owned banks which is easy to form bad loans, and the increase of general line of credit cannot reflect the development of the bank credit marketization. At the same time, there is "financial repression" in small and medium-sized enterprises in China, which needs commercial banks' financing support. So the higher level of the development of banking industry, the more non-state-owned enterprises loans. Therefore, this kind of index design can be well distinguished with credit expansion of financial institutions, which reflects China's development of banking credit marketization. 


\subsubsection{Economic Shocks Measures and Relative Controlling Variables}

Because we are unable to observe real shocks and monetary shocks directly, we need to introduce the relevant agent variables. This study uses the net value of fixed assets of industrial enterprises in China to reflect the shocks from real economy and uses the change of inflation (CPI fluctuations) to reflect monetary shocks. This study uses HP filtration method based on eviews6.0 to identify the net value of fixed assets of industrial enterprises in China and fluctuation components of price index CPI. Figure 2 and 3 show the filtering result of economic shocks ( $S H O C 1$ is annual data of net value of fixed assets of industrial enterprises in China and SHOC2 is annual date of price index CPI. Trend is trend component, and cycle is fluctuation component).

After determined the explanatory variables and explained variables, we also need to consider other possible factors of volatility of per-capita real GDP and take it as a control variable into econometric model. Dong Li (2006) believes that the development of stock market have a significant influence on China's economic fluctuations. At the same time, many domestic scholars pointed out that during the course of economic development in China, local government's behavior always played an important role in investment overheating and even economic overheating. Local governments always attract nongovernmental capital and foreign capital by means of tax concessions and land policies in condition of economic interests and political interest of their own regions. This kind of behavior of local governments is often beneficial to national economic recovery during the macroeconomic recession, while when macroeconomic runs high, if such kind of behavior of local governments cannot be controlled effectively, it will inevitably cause local economic overheating even national economic overheating. This study selects the size of government and the scale of stock market as variables by referencing Yao Yaojun and Bao Xiaohui's (2013) research.

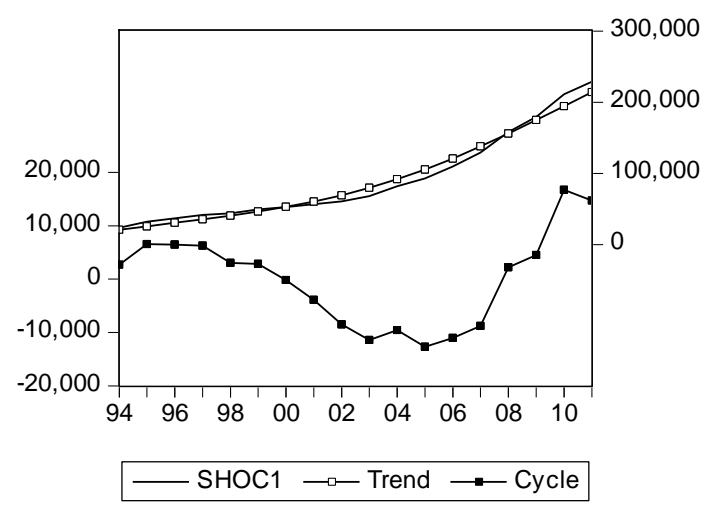

Figure 2. HP of the net value of fixed assets of industrial enterprises

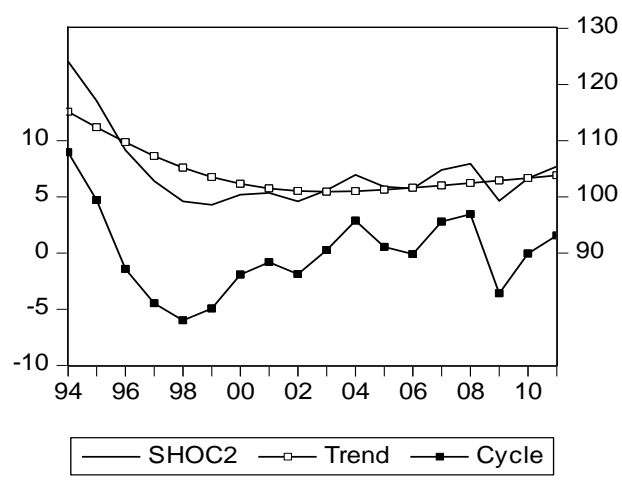

Figure 3. HP of CPI

\subsubsection{Description of Variables and Data}

The definitions of empirical index variables and related calculation methods are shown in Table 1.

Since 2010, the classification of short-term loans in Sources and Uses of Credit Funds of Financial Institutions has been changed, which makes some data incomparable to data before 2010, so this study chooses China's annual data of 1994-2010 as a sample. All the data are selected from China Statistical Yearbook and Almanac of China's Finance published by the Office for National Statistics and People's Bank of China. 
Table 1. Definition of variables

\begin{tabular}{ll}
\hline Variables & Definition \\
\hline Economic Fluctuation $(E F)$ & The fluctuation component of China's per-capita GDP growth rate after CF filtering \\
Real Shocks( $(H O C 1)$ & The fluctuation component of the net value of China's industrial enterprises after HP filtering \\
Monetary Shocks( $S H O C 2)$ & The fluctuation component of China's price index CPI after HP filtering \\
Extent of Bank Credit Marketization $(F D)$ & $\begin{array}{l}\text { The size of China's non-state-owned enterprise loan (i.e. the township enterprise loan }+ \\
\text { individual private enterprise loan + three-funded enterprise loan) }\end{array}$ \\
Size of Government $(L n G O V)$ & China's local fiscal expenditure /Natural logarithm of GDP \\
Size of Stock Market $(S M)$ & Aggregate market value of China's stock market/GDP \\
\hline
\end{tabular}

Before the econometric analysis, this study conducted a statistical description of major economic factors in order to reveal the nature of the selected data. This study analyzes the role that development of bank credit marketization plays in the conductive process of monetary fluctuation and real shocks leading to macroeconomic fluctuation in order to reflect the influence of bank credit marketization on economic fluctuation. Figure 4 and 5 are description graphs of two kinds of shocks and macroeconomic fluctuation.

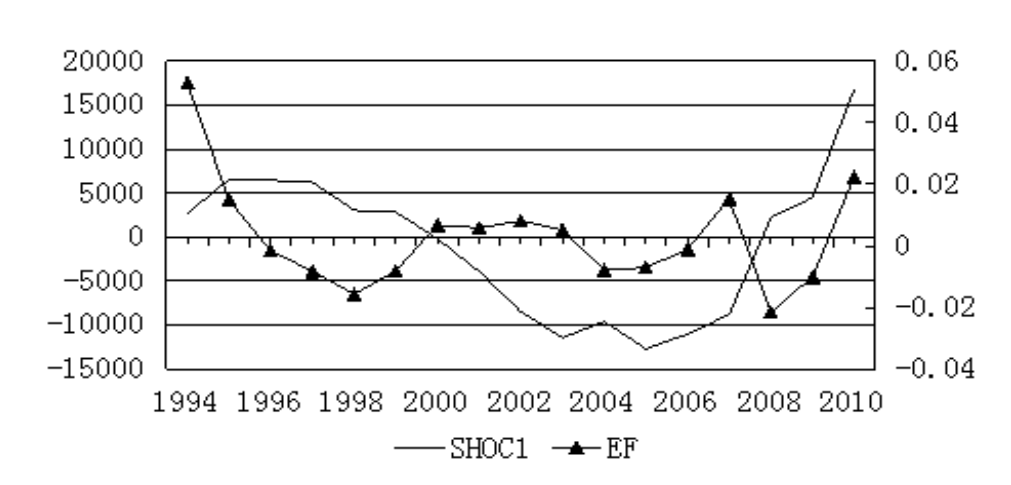

Figure 4. Real shock and economic fluctuation

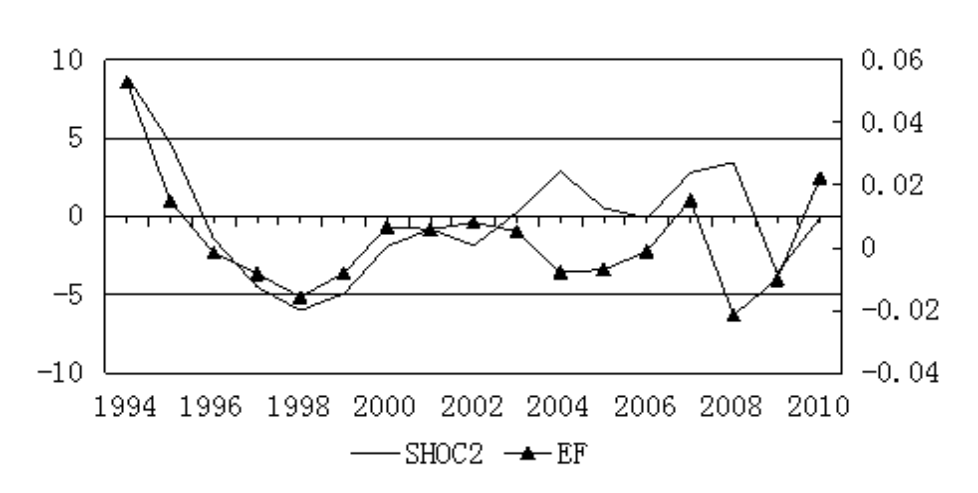

Figure 5. Monetary shock and economic fluctuation

\subsection{Econometric Model and Empirical Analysis}

According to the selected variables, the analysis on the basis of theoretical model, we build the following multivariate regression model with interaction items:

$$
\begin{aligned}
& E F_{t}=C+\alpha_{1} S H O C 1_{t}+\alpha_{2} S H O C 2_{t}+\beta F D_{t}+\varphi_{1} F D_{t} \times S H O C 1_{t} \\
& +\varphi_{2} F D_{t} \times S H O C 2_{t}+\rho_{1} \operatorname{LnGOV}_{t}+\rho_{2} S M_{t}+e_{t}
\end{aligned}
$$

In order to reveal the role that development of bank credit marketization plays in the conductive process of monetary fluctuation and real shocks leading to macroeconomic fluctuation, we need to study the coefficient of 
two interactive items in the above model especially. According to the above theoretical analysis, in the above econometric analysis model, if $\varphi_{1}$ is positive, it will mean that the development banking industrial has an amplification effect on real economy in the conductive process of output fluctuations; if $\varphi_{2}$ is negative, it will indicate that the development of banking industrial has an offset effect on monetary fluctuations in the conductive process of output fluctuations. After constructed the econometric model, this study took the following econometric analysis.

\subsubsection{Analysis of the Stability}

Table 2 shows that under the 5\% significant level, the original time series of all variables of are smooth.

Table 2. ADF test

\begin{tabular}{lcccc}
\hline Variable & Type of test $(\mathrm{c}, \mathrm{t}, \mathrm{p})$ & ADF & $5 \%$ critical value & Result \\
\hline EF & $(\mathrm{c}, 0,1)$ & -3.686078 & -3.081002 & Stable \\
SHOC 1 & $(\mathrm{c}, 0,4)$ & -3.718026 & -3.14492 & Stable \\
SHOC2 2 & $(\mathrm{c}, 0,0)$ & -3.119935 & -3.065585 & Stable \\
FD & $(\mathrm{c}, \mathrm{t}, 2)$ & -4.112183 & -3.791172 & Stable \\
LnGOV & $(\mathrm{c}, \mathrm{t}, 5)$ & -7.18616 & -3.933364 & Stable \\
SM & $(\mathrm{c}, \mathrm{t}, 0)$ & -4.089959 & -3.7332 & Stable \\
\hline
\end{tabular}

Note. $\mathrm{C}$ is the intercept, $\mathrm{T}$ is the trend, and $\mathrm{P}$ is the lag.

\subsubsection{Multiple Regression Analysis}

Because the selected time series data are all smooth, this study takes OLS regression analysis of $E F$, SHOC1, $S H O C 2, F D, F D \times S H O C 1, F D \times S H O C 2, L n G O V, S M$ by following formula (13).

The results in Table 3 show that $t$ statistic is greater than the critical value, so all of the above statistics are significant. $D W=2.080413$ illustrates that there is no self-correlation in the model, and $R^{2}=0.937188$ shows that this model is fitting, so we can explain the economic significance according to the regression coefficients.

Table 3. Results of the OLS regression

\begin{tabular}{lcccc}
\hline Variable & Coefficient & T Value & Prob. & Significance \\
\hline C & -0.075866 & -1.569008 & 0.1511 & $1 \%$ \\
SHOC 1 & -0.0000071 & -5.834128 & 0.0002 & $1 \%$ \\
SHOC2 & 0.005864 & 5.12325 & 0.0006 & $5 \%$ \\
$F D$ & -0.00000325 & -2.884294 & 0.0181 & $1 \%$ \\
$F D \times$ SHOC 1 & 0.0000000005 & 6.224704 & 0.0002 & $5 \%$ \\
$F D \times$ SHOC 2 & -0.000000343 & -3.065992 & 0.0134 & $5 \%$ \\
LnGOV & -0.046626 & -2.652853 & 0.0264 & $1 \%$ \\
SM & 0.028187 & 4.147221 & 0.0025 & 2.080413 \\
$R^{2}$ & 0.937188 & & & $D W$ \\
$R^{2}$ & 0.888334 & & & \\
\hline
\end{tabular}

1) The regression coefficient of SHOC1 is -0.0000071 , suggesting that without the participation of bank credit, the fluctuation of firms' net value and economic fluctuation are of negative correlation in China, which means that the bigger the fluctuation of firms' net value is, the smaller the economic fluctuation is and vice verse.

2) The regression coefficient of SHOC2 is 0.005864 , suggesting that without the participation of bank credit, the monetary shocks and economic fluctuation are of positive correlation, and the increase of fluctuation caused by inflation will lead to an increasing fluctuation of GDP per capita.

3) The regression coefficient of FD is -0.00000325 , suggesting that in the condition where other economic variables are controlled, the bank credit marketization slows Chinese economic fluctuation to some extent.

4) The regression coefficient of the interaction term of FD and SHOC1 is significant, fully showing that the of bank credit marketization plays a significant role in the conductive progress of Chinese real shock to macro-economy. The regression coefficient of the interaction term of FD and SHOC1 is 0. 0000000005, which 
means that with the participation of bank credit marketization, FD variable increasing per 1 unit, the influence of monetary shocks on economic fluctuation will increase 0.0000000005 units. The empirical results in this article suggest that bank credit marketization has amplifying effect in the conductive process of the macroeconomic fluctuation caused by real shocks, which proves conclusion 1 above.

5) The regression coefficient of the interaction term of FD and SHOC2 is significant, showing that Chinese bank credit marketization plays a significant role in the conductive process of Chinese real shocks to macro-economy. The regression coefficient of the interaction term of FD and SHOC2 is -0.000000343 , which means that with the participation of bank credit marketization, FD variable increasing per 1 unit, the influence of monetary shock on economic fluctuation will decrease 0.000000343 units. The empirical results in this article suggest that bank credit marketization has offset effect in the conductive process from monetary fluctuation to output fluctuation and decreases the final effect of monetary effect in fluctuation, which proves conclusion 2 above and agrees with the analysis based on the theoretical model above.

6) The positive correlation of $S M$ is high, suggesting that the fluctuation of GDP per capita is comparatively lower where the local government size is comparatively larger, which fully shows that Chinese local governments' behavior has significant influence on local economic fluctuation and the economic fluctuation is comparatively smaller where that the local government intervention is stronger. And the regression coefficient of $S M$ is 0.028187 , suggesting that the development of stock market and economic fluctuation are of positive correlation and the more developed the stock market is, the larger the economic fluctuation is.

\subsection{Explanation of the Empirical Results}

\subsubsection{Fluctuation of Firms' Net Value and of the Economy Are of Negative Correlation}

Base on Chinese financial market's situation where banks are dominant, assuming that all business capital comes from internal financing, according to Bernanke and Gertler's financial accelerator theory, firms' net value with comparatively higher level of fluctuation will not provide firms with stable investment capital, making firms' investment less, so that economic fluctuation caused by investment is reduced. Thus, in the empirical results, fluctuation of firms' net value itself has a negative influence on economic fluctuation.

\subsubsection{The Bank Credit Marketization and the Economic Fluctuation Are of Negative Correlation}

The development of bank credit marketization in China effectively increase economic ability of risk diversification in whole by reducing corporate financial constrains, encouraging industrial structure to change from sectors with higher fluctuation into sectors with lower fluctuation, encouraging the change of industrial organization's production models and other methods.

\subsubsection{The Bank Credit Marketization Amplified Real Shocks}

According to Bernanke and Gertler's theory, investment level relies on enterprises' balance sheet: comparatively higher spot asset and net value has direct positive influence, because it increases sources of internal financing, or indirect positive influence, because it reduces the cost of external financing by providing more guarantee, on investment. Because of the existence of credit friction, the cost of external financing is higher than the cost of internal financing and there exists the premium of external financing unless all of the enterprises' external financing is guaranteed. Because the level of premium of external financing and firms' net worth are of negative correlation, the asset-liability condition will lead to a change of investment, which then will give rise to an output change of next stage, so that economic fluctuation is caused, and when firms' net worth either increases or decreases because of positive or negative economic shock, this effect will be amplified by credit market. This can give an explanation to bank credit marketization's amplifying effect to economic fluctuation via real shock.

\subsubsection{The Bank Credit Marketization Reduced Monetary Shocks}

Bank credit, as one of the government's major current policies to prevent recession, has strong countercyclicality, and it is because of such countercyclicality that bank credit can restrain external economic shock, avoid dramatic economic fluctuation and smooth economic growth. On the other hand, because indirect financing holds most of the share, commercial bank is dominating in capital distribution. Monetary shocks will not only lead to macroeconomic fluctuation, but also give rise to a reversed change of money lenders' agent cost, which change will definitely have an offset effect. Thus, naturally, the development of banking industry in China does have an offset effect in the conductive process of the fluctuation caused by monetary shocks.

\subsubsection{The Stock Market Size and Economic Fluctuation Are of Positive Correlation}

he influence of stock market on economic fluctuation conforms to Chinese real situation where citizens' investment channels are limited. The capital requirements of real estate make stock market more attractive as an 
investment channel for citizens who want to manage the money matter. As the economy is in the rising period, citizens have more income, so the prosperity attracts citizens make an investment by direct ways or indirect ways such as insurance fund, making it easier for firms to financing by stock market. And the increase of firms' rolling capital enhances firms' operation capacity, encouraging the economic growth. In a similar way, when the economy is in the falling period, the flagging stock market will deepen the economic recession.

\section{Conclusion}

This article builds theoretical models to analyze how the bank credit marketization influences macroeconomic fluctuation and makes an empirical test. The conclusion shows that bank credit marketization has multi-effects in the process of economic shocks which lead to macroeconomic fluctuation: First, bank credit marketization in China has an amplifying effect in the conductive process of fluctuation caused by real shocks; Second, bank credit marketization in China has offset effects in the conductive process of fluctuation caused by monetary shock.

Based on the conclusion, this article provides the following suggestions:

\subsection{To Apply Prudential Monetary Policies}

With the development of the banking industry, the bank credit marketization has an obvious offset effect on the fluctuation caused by monetary shocks, which may change the factors that should be considered when the monetary authority applies a monetary policy. The monetary authority should be more prudential to monetary policies and take advantage of bank credit marketization's characteristic to facilitate the smooth economic growth.

\subsection{To Propel the Reform of Chinese Bank Credit Marketization and to Increase Bank Credit Efficiency}

To provide a stable environment for Chinese economic growth in the long run and to avoid dramatic macroeconomic fluctuation, it is necessary to propel the reform of Chinese bank credit marketization so that Chinese bank credit size can be expanded and Chinese bank credit efficiency can be increased. Considering that the main performance of Chinese low-efficient bank credit market is the distortion in Chinese financial system and the feature that it is difficult for non state-owned economic sectors to finance from financial system, we provide the following suggestions:

First, to propel powerful promotion to middle and small size financial administration, decreasing state-owned commercial banks' share in Chinese financial system, improving the industrial structure of Chinese banking industrial structure and building up a modern banking system which can offer better financial supports to non state-owned economic sectors.

Second, to strive to develop capital markets, especially the growth enterprise market which can provide financing service for non state-owned enterprises to expand the financing channel of non state-owned economic sectors.

\subsection{To Enhance Government's Supervision and Government's Role in Macro-Control}

Learning from the lesson of Subprime Mortgage Crisis, in the process of promoting economic growth by the marketization of banking in China, it is the quality instead of just quantity of the capital that should be paid more attention to and government's supervision should be enhanced because government's administrative measure to restrict credit is essential in restraining the fluctuation of economic growth. In a nutshell, government should play a proper role in macro-economic control.

\subsection{To Improve Chinese Financial Structure and to Balance Bank Credit and Stock Market}

Financial structure has an obvious influence on macroeconomic fluctuations and it is important to improve Chinese financial structure, and to allocate proper proportion of direct financing and indirect financing and to have effective supervision on bank and stock market. In the future, relative government sectors should continue to be prudential and concentrate on how to take advantage of these two distinct policies, bank credit channel and financing by stock market, and make a rational coordination to promote economic growth.

\section{Acknowledgment}

This study is sponsored by the Shandong Research Award Fund for Outstanding Young Scientists (Number: BS2011SF008), the Shandong Social Science Planning Major Commissioned Project (Number: 14AWJT01-5), the Ministry of Education of Humanities and Social Sciences Planning Project (2015) "A Regional Difference Research on Shadow Banking's Financial Risk in China: Characteristics, Measurement and Precaution"(Number: forthcoming), and by the Project of the National Natural Science Foundation of China, 
“Shadow Banking, Credit Transmission and The Asymmetric Effect of Monetary Policy" (Number: 71573156).

\section{References}

Aghion, P., Angeletos, G. M., Banerjee, A., \& Manova, K. (2010). Volatility and growth: Credit constraint and the composition of investment. Journal of Monetary Economics, 57(3), 246-265. http://dx.doi.org/10.1016/j.jmoneco.2010.02.005

Aghion, P., Bacchetta, P., \& Banerjee, A. (2004). Financial development and the instability of open economies. Journal of Monetary Economics, 51(6), 1077-1106. http://dx.doi.org/10.1016/j.jmoneco.2003.12.001

Bacchetta, P., \& Caminal, R. (2000). Do capital market imperfections exacerbate output fluctuations? European Economic Review, 44, 449-468. http://dx.doi.org/10.1016/S0014-2921(98)00083-X

Bartram, S., \& Wang, Y. (2015). European financial market dependence: An industry analysis. Journal of Banking \& Finance, 59, 146-163. http://dx.doi.org/10.1016/j.jbankfin.2015.06.002

Bernanke, B., \& Gertler, M. (1989). Agency costs, net worth and business fluctuations. American Economic Review, 79(1), 14-31. http://www.jstor.org/stable/1804770

Bernanke, B., Gertler, M., \& Gilchrist. (1996). Financial accelerator and the flight to quality. The Review of Economics and Statistics, 78(1), 1-15. http://dx.doi.org/10.2307/2109844

Bing, Z. (2015). The Regional finance development and economic convergence and divergence: Based on provincial data in China. Economic Issues Exploration (China), 8, 134-141. http://dx.doi.org/10.14136/j.cnki.cn33-1336/f.2015.08.019

Cacciatore, M., Ghironi, F., \& Stebunovs, V. (2015). The domestic and international effects of interstate U.S. $\begin{array}{lllll}\text { banking. Journal of International } & \text { Economics, } & \text { 95(2), } & \text { 171-187. }\end{array}$ http://dx.doi.org/10.1016/j.jinteco.2014.12.001

Dangwei, B. (2004). Financial development and endogenous economic fluctuation. Economist (China), 16, 87-93. http://dx.doi.org/10.16158/j.cnki.51-1312/f.2004.02.015

Dellas, H., \& Hess, M. K. (2002). Financial development and the sensitivity of stock markets to external influences. Review of International Economics, 10, 525-538. http://dx.doi.org/10.1111/1467-9396.00348

Demirgüç-Kunt, A., \& Detragiache, E. (1998). Financial Liberalization and Financial Fragility. Policy Research Working Paper, 3, 1-53.

Denizer, C., Iyigun, M. F., \& Owen, A. L. (2002). Finance and macroeconomic volatility. Contributions to Macroeconomics, Berkeley Electronic Press, 2, 427-481. http://dx.doi.org/10.1596/1813-9450-2487

Dong, L. (2006). An empirical study of the financial development and the economic growth. Economy and Management (China), 14, 84-87.

Easterly, W., Islam, R., \& Stiglitz, J. (2000). Shaken and stirred: Ex-plaining growth volatility. Annual World Bank Conference on Development Economics, 191-211.

Guoyu, J., \& Yi, L. (2005) The change of the micro economic bases of China's cyclical economic fluctuation. China's Social Science, 1, 60-70.

Hausmann, R., \& Gavin, M. (1996). Securing stability and growth in a shock prone region: The policy challenge for Latin America. Working Paper, NY: Inter-American Development Bank, Office of the Chief Economist (Vol. 315, pp. 1-57).

Kaminsky, G., \& Reinhart, C. M. (1996). The Twin Crisis: The Causes of Banking and Balance of Payments Problems. Federal Reserve Board, Washington, D.C

Kiyotaki, N., \& Moore, J. (1997). Credit cycles. Journal of Political Economics, 105(2), 211-248. http://dx.doi.org/10.1086/262072

Ogawa, K. (2015). Firm investment, liquidity and bank health: A panel study of Asian firms in the 2000s. Journal of Asian Economics, 38, 44-54. http://dx.doi.org/10.1016/j.asieco.2015.03.002

Pitterle, I., Haufler, F., \& Hong, P. (2015). Assessing emerging markets' vulnerability to financial crisis. Journal of Policy Modeling, 37(3), 484-500. http://dx.doi.org/10.1016/j.jpolmod.2015.03.010

Raddatz, C. (2006). Liquidity needs and vulnerability to financial underdevelopment. Journal of Financial Economics, 80, 677-722. http://dx.doi.org/10.1016/j.jfineco.2005.03.012

Shucheng, L.. (2009). A review and a forecast of the past 60 years' economic growth in China: An observation of 
the new cycle. Economics Trend $\quad$ (China), 10, http://dx.doi.org/10.19834/j.cnki.cn33-2049/f.2009.10.029

Stiglitz, J. E., \& Marilou, U. Y. (1996). Financial markets, public policy, and the East Asian miracle. World bank Research Observer, 11(2), 249-276. http://dx.doi.org/10.1093/wbro/11.2.249

Stiglitz, J. E., \& Weiss, A. (1981). Credit rationing in market with imperfect information. America Economic Review, 71(3), 393-410.

Thorsten, B., Mattias, L., \& Giovanni, M. (2006). Financial intermediary development and growth volatility: Do intermediaries dampen or magnify shocks? Journal of International Money and Finance, 25, 1146-1167. http://dx.doi.org/11.1049/wbro/11.3.243

Ting, D., \& Dong, P. (2006). Relationship between financial shocks and economic fluctuation: From their perspectives. The Central Fiance and Economics University Journal (China), 20, 38-45.

Tong, Z., Xin, Q., \& Lei, L. (2011). Financial development, exogenous shocks and economic fluctuations: A study of China's provincial data. Commercial Economy and Management (China), 1, 52-59. http://dx.doi.org/10.14134/j.cnki.cn33-1336/f.2011.01.004

Wang, P., \& Wen, Y. (2009). Financial development and economic volatility: A unified explanation. Working Papers NO.2009-022c, Federal Reserve Bank of St. Louis. http://dx.doi.org/10.2139/ssrn.1396720

Yaojun, Y., \& Xiaohui, B. (2013). Does financial intermediaries moderate economic fluctuations? Finance and Economic Study (China), 39, 61-81. http://dx.doi.org/10.14394/j.cnki.cn33-1330/f.2013.09.093

Zhenxin, L., \& Yabin, D. (2009). The development of the banking industry and the macro economy of China. $\begin{array}{lllll}\text { Contemporary Economic } & \text { Science } & \text { (China), } & 1, & \text { 65-71. }\end{array}$ http://dx.doi.org/10.143095/j.cnki.cn33-1942/f.2009.01.024

\section{Copyrights}

Copyright for this article is retained by the author(s), with first publication rights granted to the journal.

This is an open-access article distributed under the terms and conditions of the Creative Commons Attribution license (http://creativecommons.org/licenses/by/3.0/). 